\title{
DISFUNGSIONALISASI BIROKRASI SEBAGAI KENDALA DALAM PEMBERANTASAN KORUPSI
}

\author{
Anastasia Reni Widyastuti \\ Fakultas Hukum Unika. St. Thomas Sumatera Utara Medan \\ E-mail : widyastutireni@yahoo.co.id
}

\begin{abstract}
Combating corruption is believed to be able to create a clean government and create a sense of justice. The creation of state administration are clean and free of corruption is not only the responsibility of the organizers of the state alone, but also society and all parts of the nation. Community participation required to perform social control over governance practices, particularly in the government bureaucracy. Corruption is an enemy of the nation, so handling should be made a priority by all components of the nation through law enforcement, both in micro through criminal law instrument also macro enforcement through improved legal substance, legal structure and legal culture of society. Government in tackling corruption should continue to perform the steps of effective and thorough manner: empowering moral integrity of law enforcement; socialization understanding of corruption; legal sanctions; form a network of corruption prevention, optimizing oversight agencies. One effort to fix and prevent the occurrence of corruption is not only necessary to improve the quality of public services through good governance and clean, to implement the principles of good governance but also to accelerate the eradication of corruption is an integral synergies and systemic, so the bureaucracy can be run in accordance with its function each.
\end{abstract} Keywords: disfungsionalisasi, bureaucracy, corruption.

\begin{abstract}
Abstrak
Pemberantasan korupsi diyakini mampu menciptakan pemerintahan yang bersih dan menciptakan rasa keadilan. Penciptaan administrasi negara yang bersih dan bebas dari korupsi bukan hanya menjadi tanggung jawab penyelenggara negara saja, tetapi juga masyarakat dan semua bagian dari bangsa. Partisipasi masyarakat diperlukan untuk melakukan kontrol sosial terhadap praktik tata kelola, khususnya dalam birokrasi pemerintahan. Korupsi adalah musuh bangsa, sehingga prioritas penanganan harus dilakukan oleh seluruh komponen bangsa melalui penegakan hukum, baik secara mikro melalui instrumen hukum pidana juga penegakan makro melalui perbaikan substansi hukum, struktur hukum dan budaya hukum masyarakat. Pemerintah dalam menanggulangi korupsi harus terus melakukan langkah-langkah yang efektif dan menyeluruh: dengan memberdayakan integritas moral penegak hukum; pemahaman sosialisasi korupsi; sanksi hukum; membentuk jaringan pencegahan korupsi, mengoptimalkan lembaga pengawasan. Salah satu upaya untuk memperbaiki dan mencegah terjadinya korupsi tidak hanya diperlukan untuk meningkatkan kualitas pelayanan publik melalui pemerintahan yang baik dan bersih, untuk melaksanakan prinsip-prinsip tata kelola yang baik, tetapi juga untuk mempercepat pemberantasan korupsi merupakan sinergi integral dan sistemik, sehingga birokrasi dapat berjalan sesuai dengan fungsinya masing-masing.
\end{abstract}

Kata kunci: disfungsionalisasi, birokrasi, korupsi. 


\section{A. Pendahuluan}

Negara Indonesia dikenal secara luas sebagai salah satu negara yang paling korup. Praktek korupsi telah meluas secara horizontal maupun vertikal, berkembang terus menerus secara kuantitatif dan kualitatif. Namun ironisnya sedikit sekali koruptor yang diadili dan dijatuhi pidana. Korupsi itu jelas telah menghambat atau menggagalkan upaya pembangunan di Indonesia, maka semua pihak mempunyai keinginan agar korupsi dicegah atau diberantas secepat mungkin. Korupsi di Indonesia sudah merupakan kejahatan yang disebut sebagai extra-ordinary crime, sehingga tuntutan ketersediaan perangkat hukum yang sangat luar biasa dan canggih serta kelembagaan yang menangani korupsi tersebut tidak dapat dielakkan lagi. Persoalan pemberantasan korupsi di Indonesia bukan hanya persoalan hukum saja, melainkan juga persoalan sosial dan psikologi, sehingga wajib dibenahi secara simultan (Romli Atmasasmita, 2003: 25).

Korupsi bukan hanya terjadi di Indonesia, tetapi juga di seluruh dunia. Hal tersebut sebagaimana tercantum dalam preambul ke-4 United Nations Convention Againts Corruption, tahun 2003 yang menyatakan: "meyakini bahwa korupsi tidak lagi merupakan masalah lokal, melainkan suatu fenomena transnasional yang mempengaruhi seluruh masyarakat dan ekonomi yang mendorong kerja sama internasional untuk mencegah dan mengontrolnya secara esensial (Ermansjah Djaja, 2010: 3).

Berbagai upaya melalui "law reform” dan "law enforcement” tidak menunjukkan hasil yang maksimal. Ternyata hukum bukan obat yang manjur untuk menanggulangi korupsi, ia hanya merupakan salah satu strategi saja yang dapat dipilih untuk memberantas korupsi. Bahkan para ahli hukum pidana banyak yang menyatakan bahwa hukum pidana hanya mengatasi symptom korupsi saja, bukan mengatasi kausanya. Kausa dari kejahatan pada umumnya, korupsi khususnya antara lain adalah kebodohan, ketidak-tahuan, pesimisme dan ketidak-pedulian yang akhirnya berdampak buruk pada bertambahnya kualitas dan kuantitas kemiskinan dalam masyarakat (Marcella Elwina S, 2011: 3).

Penanggulangan korupsi, supaya berhasil penting sekali melibatkan masyarakat sipil. Karena upaya apapun yang dilakukan untuk mengembangkan strategi anti korupsi tanpa melibatkan masyarakat sipil akan sia-sia karena umumnya negara yang peran serta masyarakat sipilnya rendah, tingkat korupsinya akan tinggi. Ellie Keen menyatakan bahwa masyarakat sipil memiliki andil yang cukup besar untuk terjadinya korupsi, sehingga keterlibatannya dalam menanggulangi korupsi menjadi sangat esensial dan merupakan suatu keharusan (Marcella Elwina S, 2011: 3-4). 


\section{B. Penanggulangan korupsi}

Korupsi dalam Black’s Law Dictionary adalah “suatu perbuatan yang dilakukan dengan maksud untuk memberikan suatu keuntungan yang tidak sesuai dengan kewajiban resmi dan hak-hak dari pihak-pihak lain, secara salah menggunakan jabatannya atau karakternya untuk mendapatkan suatu keuntungan untuk dirinya sendiri atau untuk orang lain, bersamaan dengan kewajibannya dan hak-hak dari pihak lain (Henry Cambell Black, 1990).

Pengertian korupsi dalam Undang-undang Nomor 31 Tahun 1999 jo. Undangundang Nomor 20 Tahun 2001 tentang Pemberantasan Tindak Pidana Korupsi, dikelompokan menjadi: (1) delik yang dapat merugikan keuangan negara; (2) delik penyuapan; (3) delik penggelapan; (4) delik pemerasan dalam jabatan; (5) delik yang berkaitan dengan pemborongan, leveransir dan rekanan. Dengan memahami pengertian korupsi, diharapkan pemberantasan korupsi dalam bentuk pencegahan dan penindakan dapat diwujutkan, sehingga pemberantasan korupsi tidak hanya memberikan efek jera, tetapi juga berfungsi sebagai daya tangkal.

Sampai saat ini masih terdapat kecenderungan bahwa segala permasalahan hanya dapat diselesaikan dengan undang-undang, padahal hukum baru bermakna apabila dijalankan dan ditegakkan dalam praktek secara nyata. Jika penerapan suatu peraturan perundang-undangan tidak dilakukan secara integral dan tidak diikuti upaya sistemik lainnya, terutama tindakan pencegahan, maka penegakan hukum tersebut masih kurang maknanya dalam upaya pemberantasan korupsi (Marwan Effendy, 2012: 6).

Harus kita sadari bahwa sanksi pidana saja tidak dapat menjamin turunnya perilaku yang koruptif dari masyarakat. Perilaku yang koruptif tersebut tumbuh subur karena dorongan dari masyarakat sendiri, yang ingin mendapatkan pelayanan secara instan tanpa melalui prosedure yang baku. Perilaku sebagian masyarakat yang demikian itu secara tidak sadar telah menghancurkan integritas para petugas, penguasa atau pihak-pihak yang berwenang.

Masalah penanggulangan korupsi melalui upaya pencegahan dalam konferensi ketiga PBB di Doha tanggal 9 s/d 13 Nopember 2009 yang telah lalu, dari 4 resolusi yang dihasilkan ternyata masalah pencegahan masih mendapat perhatian yang serius dari peserta konferensi tersebut. Hal itu terlihat bahwa dari 4 resolusi yang dihasilkan tersebut, masalah pencegahan ditempatkan pada urutan kedua setelah kajian mekanisme penanggulangan tindak pidana korupsi. Selanjutnya urutan ketiga pengembalian aset dan yang keempat bantuan teknis (Marwan Effendy, 2012: 7). 
Korupsi terkait dengan berbagai permasalahan, tidak hanya masalah hukum dan penegakannya, tetapi juga menyangkut masalah moral/sikap mental, masalah pola hidup, budaya dan lingkungan sosial, masalah kebutuhan ekonomi dan kesenjangan sosialekonomi, masalah sistem ekonomi, masalah sistem politik, serta masalah mekanisme pembangunan dan lemahnya birokrasi administrasi termasuk sistem pengawasan di bidang keuangan dan pelayanan publik. Jadi kausa dan kondisi yang bersifat kriminogen untuk timbulnya korupsi sangatlah luas (multidimensi), antara lain bisa di bidang moral, sosial, ekonomi, politik, budaya, birokrasi/administrasi (Nyoman Serikat Putra Jaya, 2008: 71).

Upaya pemerintah untuk memberantas korupsi sudah dimulai sejak tahun 1957 dengan membuat peraturan perundang-undangan sebagai alat untuk memberantas korupsi, antara lain:

1. Peraturan Penguasa Militer untuk Daerah Kekuasaan Angkatan Darat No. Prt/PM06/1957 tanggal 9 April 1957 tentang Pemberantasan Koropsi;

2. Peraturan Penguasa Militer No. Prt/PM-08/1957 tentang Penilikan Terhadap Harta Benda;

3. Peraturan Penguasa Perang Pusat Angkatan Darat No. Prt/Peperpu/013/1958, 13 April 1958 tentang Pengusutan, Penuntutan dan Pemeriksaan Perbuatan Korupsi dan Penilikan Harta Benda;

4. Peraturan Penguasa Perang Pusat Kepala Staf Angkatan Laut No. Prt/Z.I/I/7 tanggal 17 April 1958;

5. Peraturan Pemerintah Pengganti Undang-undang No. 24 Tahun 1960 tanggal 9 Juni 1960 tentang Pengusutan, Penuntutan dan Pemeriksaan Tindak Pidana Korupsi, yang menurut Undang-undang No. 1 Tahun 1961 telah menjadi Undang-Undang dan disebut Undang-Undang Nomor 24 Prp Tahun 1960, sejak tanggal 1 Januari 1961;

6. Undang-undang Nomor 3 Tahun 1971 tentang Pemberantasan Tindak Pidana Korupsi;

7. Undang-undang Nomor 28 Tahun 1999 tentang Penyelenggaraan Negara yang bersih dan bebas dari Korupsi, Kolusi dan Nepotisme;

8. Undang-undang Nomor 31 Tahun 1999 tentang Pemberantasan Tindak Pidana Korupsi;

9. Undang-undang Nomor 20 Tahun 2001 tentang Perubahan atas Undang-undang Nomor 31 Tahun 1999 tentang Pemberantasan Tindak Pidana Korupsi;

10. Undang-undang Nomor 30 Tahun 2002 tentang Komisi Pemberantasan Tindak Pidana Korupsi.

Di samping itu Pemerintah juga telah mengeluarkan:

1. Peraturan Pemerintah Republik Indonesia Nomor 19 Tahun 2000 tanggal 5 April 2000 tentang Tim Gabungan Pemberantasan Tindak Pidana Korupsi;

2. Peraturan Pemerintah Republik Indonesia Nomor 71 Tahun 2000 tanggal 21 Agustus 2000 tentang Tata Cara Pelaksanaan Peran Serta Masyarakat dan Pemberian Penghargaan dalam Pencegahan dan Pemberantasan Tindak Pidana Korupsi (S. Anwary, 2005: 133-134). 
Ternyata peraturan perundang-undangan tersebut belum memberikan hasil sebagaimana yang diharapkan. Masalah hukum yang menjadi tuntutan adalah mengenai penegakan dan penerapannya, atau law enforcement. Sesungguhnya hukum berperan untuk mengantarkan masyarakat kepada kesejahteraan dalam hidupnya (Jeremy Bentham, 2006: 26).

Seorang filosof hukum aliran realisme bernama Wilhelm Lundsted mengatakan bahwa hukum itu bukan apa-apa (law is nothing) (Antonius Sujata, 2000: 6). Pendapat itu cukup masuk akal bagi Indonesia karena terbukti bahwa dengan banyaknya aturan, ternyata juga makin banyak tuntutan. Secara lengkap Wilhelm Lundsted kemudian menegaskan bahwa hukum baru memiliki makna setelah ditegakkan. Tanpa penegakan, hukum bukan apa-apa (Satjipto Rahardjo, 2008: 6).

Satjipto Rahardjo menyatakan penegakan hukum adalah suatu proses untuk mewujudkan keinginan-keinginan hukum menjadi kenyataan. Keinginan-keinginan hukum adalah pikiran-pikiran badan pembuat undang-undang yang dirumuskan dalam peraturan-peraturan hukum. Penegakan hukum dimulai dari pembuatan sampai ke pelaksanaan undang-undang tersebut. Keinginan-keinginan hukum dilakukan melalui manusia, sehingga manusia yang menjalankan penegakan hukum benar-benar menempati kedudukan yang penting dan menentukan (Satjipto Rahardjo, 2009: 1-2).

Relevan dengan hal tersebut B.M. Taverne menyatakan: berikan padaku hakim yang baik, jaksa yang baik serta polisi yang baik, maka dengan hukum yang buruk sekalipun, saya bisa mendatangkan keadilan. Artinya, bagaimanapun lengkapnya suatu rumusan undang-undang, tanpa didukung aparatur penegak hukum yang baik, memiliki moralitas dan integritas yang tinggi, maka hasilnya akan buruk (Satjipto Rahardjo, 2007: $6)$.

\section{Disfungsionalisasi Birokrasi}

Negara merupakan wadah utama birokrasi yang di dalamnya diselenggarakan proses untuk mencapai tujuan suatu masyarakat bangsa. Penyelenggaraan proses pencapaian tujuan tersebut adalah pemerintah dengan komponen-komponen dan kelengkapannya yang disebut dengan birokrasi. Maka banyak yang mengidentikan dalam artian luas, negara adalah pemerintah dan pemerintah adalah birokrasi walau dalam kajian-kajian spesifik bisa ditarik garis -garis perbedaan.

Birokrasi menurut Blow dan Meyer adalah organisasi besar yang merupakan lembaga yang sangat berkuasa, yang mempunyai kemampuan sangat besar untuk berbuat kebaikan atau keburukan (Peter Blow dan W. Meyer Marshall, 1987: 5). Sedangkan 
Mac Weber yang dikenal sebagai bapak birokrasi, optimis bahwa birokrasi mengandung hal-hal positif yang dikenal sebagai birokrasi ideal, yaitu:

1. Pembagian tugas dengan cara yang telah ditentukan (spesialisasi).

2. Setiap jenjang melaksanakan tugas sesuai kewenangan dan dikontrol oleh atasan.

3. Peraturan perundangan yang jelas dan konsisten.

4. Formal dan tidak bersifat pribadi.

5. Pembinaan karier yang didasarkan atas senioritas atau prestasi.

6. Penghargaan terhadap pengalaman, prestasi dan jasa David Osborne and Ted Gabler, 1995: 52).

Sehat atau tidaknya birokrasi sangat dipengaruhi oleh persepsi aparatnya tentang segi kehidupan instansi tempatnya bekerja, tentang justifikasi eksis peranan yang diembannya, batas wewenangnya tugas-tugas fungsionalnya. Beberapa bentuk penyakit birokrasi yang mengakibatkan terjadinya disfungsionalisasi birokrasi antara lain sebagai berikut:

1. Penyalahgunaan wewenang dan jabatan. Kecenderungan ini terjadi pada pejabat yang relatif sudah lama menduduki suatu jabatan. Pejabat yang menyalahgunakan wewenang dan jabatannya ini dalam kesehariannya lebih berorientasi pada kewenangan/authority oriented daripada orentasi pelayanan masyarakat.

2. Phobia kritik. Banyak aparat yang sangat tabu terhadap kritik, yang datang dari masyarakat maupun dari sesama aparat. Kritik selalu dihadapi dengan suatu persepsi bahwa kritik akan merongrong wibawa dan jabatannya. Padahal sebaliknya, dengan kritik yang sering muncul seorang pejabat akan selalu diingatkan, dikembangkan agar terus kritis dan kreatif dalam upaya memberi pelayanan kepada masyarakat.

3. Korupsi dan Sogok. Korupsi dan sogok merupakan penyakit birokrasi yang sangat merugikan karena akan mengakibatkan biaya tinggi dan memunculkan ketidakadilan. Dari kedua perilaku disfungsional aparat ini, kelompok terakhir yang dirugikan adalah rakyat. Penyakit jenis inilah yang sekarang sangat mewabah di Indonesia, dan telah menjalar hampir di semua strata. Korupsi telah menjadi budaya di Indonesia, orang tidak lagi malu menunjukkan gaya hidup mewah dari hasil korupsi.

4. Kecenderungan mempertahankan status Quo. Mereka yang sudah menduduki posisi enak cenderung tidak mau terjadi perubahan yang mengancam kedudukan, walaupun dengan cara itu membuat rakyat banyak dalam keadaan menderita. Untuk mempertahankan status quo, aparat ini memperkuat dan memperluas kekuasaannya dengan menempatkan orang-orang disekelilingnya (nepotisme). Di samping itu sering 
pula melakukan pendekatan yang bersifat represif dengan dalih keamanan dan stabilitas.

5. Boros dan mewah. Banyak dana/anggaran digunakan untuk kegiatan-kegiatan rutin, sementara dana yang digunakan untuk pelayanan masyarakat relatif kecil. Kegiatan rutin termasuk di dalamnya untuk pemeliharaan mobil yang pemakaiannya tidak hanya untuk kepentingan dinas tetapi juga digunakan pada saat-saat libur, belanja keluarga dan kepentingan keluarga lainnya.

6. Arogansi/sombong. Kesombongan bisa disebabkan kesenjangan dengan rakyat yang berupa: ekonomi, status sosial, fasilitas yang dapat menjauhkan aparat dengan rakyat yang diwakili dan yang harus dilayani.

7. Ragu dalam mengambil keputusan. Keputusan adalah inti dari kepemimpinan, justru keraguan mengambil keputusan bisa karena kurangnya tingkat kompetensi atau takut akan resiko dan berpikir lebih baik safety. Orang yang berfikir safety, meyakini tidak banyak bertindak maka berarti tidak banyak kesalahan yang dilakukan, akan tetapi harus diyakini pula bahwa tidak banyak bertindak berarti tidak banyak produksi.

8. Kurang koordinasi. Hal ini akan membuat in efisiensi kerja aparatur birokrasi karena tidak tercapainya sinergisme dan kesisteman. Semua aparat seharusnya memahami bahwa mereka adalah bagian integral dari tugas-tugas birokrasi secara keseluruhan. Untuk dapat melakukan koordinasi dengan baik, seorang pejabat harus memahami persis apa yang menjadi tugas pokok dan fungsinya, juga memahami tugas dan fungsi instansi lain. Dengan pemahaman tersebut maka akan dipahami keterkaitan antar instansi sebagai suatu sistem yang lebih besar saling mempengaruhi dan saling tergantung.

9. Cepat puas diri. Sehingga malas melakukan kreativitas, inovasi, tidak mampu melakukan eksperimentasi padahal lingkungannya telah berubah dengan berbagai paradigma baru yang sangat cepat, hal ini membuat aparat birokrasi tertinggal dan akan menjadi inkompeten. Kenyataan saat ini dapat dilihat bahwa kemajuan sumber daya manusia instansi swasta jauh lebih cepat, karena tidak dihinggapi rasa puas diri. Di samping itu instansi swasta benar-benar menghayati situasi kompetisi global untuk mempertahankan eksistensinya.

10. Kurangnya pengetahuan dan keterampilan. Adakalanya pelayanan yang diberikan kurang memadai, karena kurangnya pengetahuan dan keterampilan yang dimilikinya. Maka pembinaan dan peningkatan kualitas aparat harus secara terus menerus dilaksanakan, di samping itu perlu ditetapkan secara jelas syarat-syarat suatu jabatan, 
demikian juga dalam hal rekruitmen pegawai baru. Hal lain yang perlu diperhatikan adalah kaderisasi yang terus menerus agar tidak terjadi stagnasi jabatan.

11. Perilaku yang disfungsional. Seluruh aparat birokrasi di negara manapun adalah abdi negara dan abdi masyarakat, "public servant” aparat yang dalam tugasnya berorientasi pada pelayanan, maka sesuai profesi dan fungsi aparat harus berperilaku fungsional dalam melaksanakan tugas-tugasnya. Dalam menghadapi klien (rakyat), aparat tidak seharusnya sombong, pura-pura sibuk, acuh tak acuh, diskriminatif, kaku, berbelitbelit (red tape), kerja asal-asalan, mengutamakan kepentingan pribadi, melampaui batas wewenang, boros, interest pribadi, dan sikap perilaku lain yang tidak menyenangkan. Setiap aparat birokrasi diharapkan mempunyai kompetensi yang sedikitnya memenuhi 3 (tiga) syarat yaitu: knowledge, skill dan attitude.

Upaya pemerintah dalam melakukan penanggulangan tindak pidana korupsi, baik melalui penindakan yang dilakukan oleh aparat penegak hukum maupun melalui reformasi birokrasi diberbagai sektor publik dan administratif yang dilakukan oleh pemerintah masih menemui kendala. Belum tuntasnya program tersebut karena kelembagaan (institution), ketatalaksanaan (business process) dan sumber daya manusia (human resource) terkait dengan masalah pelayanan publik/masyarakat (public service), prosedur untuk berinvestasi (investment prosedure), proses untuk mendapatkan keadilan (access to justice) serta dalam pengadaan barang dan jasa di pemerintahan (government good and service procurement) belum sesuai dengan harapan masyarakat.

Masyarakat luas yang mempunyai keinginan berperan serta dalam usaha pemberantasan korupsi dapat menyalurkan peran sertanya pada lembaga kepolisian, kejaksaan, atau Komisi Pemberantasan Korupsi dengan cara melaporkan adanya dugaan tindak pidana korupsi yang dilakukan pegawai negeri atau penyelenggara negara, disertai dengan bukti-bukti yang lengkap sehingga laporan tidak merupakan fitnah. Dengan demikian ada tiga jalur yang dapat ditempuh masyarakat apabila ingin berperan serta dalam usaha pemberantasan tindak pidana korupsi di Indonesia.

Pertama, jalur kepolisian pada tingkat penyelidikan dan penyidikan. Kewenangan pihak kepolisian dalam menangani perkara tindak pidana korupsi, setelah menerima laporan dari masyarakat hanya pada tingkat penyelidikan dan penyidikan. Jika penyidikan sudah dianggap selesai dalam arti sudah dibuat berita acara pemeriksaan disertai dengan bukti-bukti yang sah, serta menurut penilaian jaksa penuntut umum berkas perkara sudah dianggap lengkap. Pihak kepolisian melimpahkan berkas perkara 
tersebut kepada jaksa penuntut umum untuk selanjutnya pihak jaksa penuntut umum melimpahkan ke pengadilan untuk diperiksa dan diputus.

Kedua, jalur kejaksaan di mana dalam hal ini pihak kejaksaan mempunyai fungsi ganda, yaitu sebagai penyidik dan penuntut umum. Pihak kejaksaan setelah menerima laporan dari masyarakat tentang adanya dugaan tindak pidana korupsi, baik pada suatu institusi pemerintah maupun swasta mempunyai wewenang untuk melakukan penyelidikan dan penyidikan, serta melimpahkan perkara tindak pidana korupsi tersebut ke pengadilan. Hasil penyidikan yang dilakukan oleh pejabat kepolisian maupun kejaksaan, oleh jaksa penuntut umum dilimpahkan ke pengadilan melalui jalur biasa, yaitu jalur pengadilan umum (pengadilan negeri - pengadilan tinggi - Mahkamah Agung), dengan menggunakan hukum acara biasa ditambah dengan hukum acara yang diatur dalam Undang-Undang Nomor 31 Tahun 1999 jo. Undang-Undang Nomor 20 Tahun 2001.

Ketiga, jalur Komisi Pemberantasan Tindak Pidana Korupsi, di mana komisi ini merupakan lembaga yang independen dan bebas dari pengaruh pihak manapun. Komisi Pemberantasan Korupsi dalam hal ini mempunyai wewenang untuk melakukan penyelidikan penyidikan, serta penuntutan terhadap perkara tindak pidana korupsi. Dalam hal Komisi Pemberantasan Korupsi menerima laporan dari masyarakat tentang adanya dugaan tindak pidana korupsi, baik pada suatu instansi pemerintah maupun swasta, maka komisi ini mempunyai kewenangan untuk melakukan penyelidikan, penyidikan, dan penuntutan. Ini berarti Komisi Pemberantasan Korupsi mempunyai lembaga penyelidik, penyidik, dan penuntut umum tersendiri, yang diangkat dan diberhentikan oleh Komisi Pemberantasan Korupsi. Pengadilan yang memeriksa dan memutus tindak pidana korupsi yang penuntutannya diajukan oleh Komisi Pemberantasan Korupsi adalah pengadilan tindak pidana korupsi yang dibentuk berdasarkan Undang-Undang Nomor 30 Tahun 2002 tentang Komisi Pemberantasan Tindak Pidana Korupsi.

Pengadilan tindak pidana korupsi berada di lingkungan peradilan umum dan untuk pertama kali dibentuk pada Pengadilan Negeri Jakarta Pusat yang wilayah hukumnya meliputi seluruh wilayah Republik Indonesia (Pasal 54 Undang-Undang Nomor 30 Tahun 2002). Pengadilan Tindak Pidana Korupsi ini terdiri atas tingkat pertama (pengadilan negeri), tingkat banding dan kasasi.

Beberapa ketentuan dalam Undang-Undang Nomor 30 Tahun 2002 yang perlu mendapat perhatian, antara lain: 
Pasal 39:

(1) Penyelidikan, penyidikan, dan penuntutan tindak pidana korupsi dilakukan berdasarkan hukum acara pidana yang berlaku dan berdasarkan Undang-Undang Nomor 31 Tahun 1999 tentang Pemberantasan Tindak Pidana Korupsi sebagaimana telah diubah dengan Undang-Undang Nomor 20 Tahun 2001 tentang Perubahan atas Undang-Undang Nomor 31 Tahun 1999 tentang Pemberantasan Tindak Pidana Korupsi, kecuali ditentukan lain dalam undang-undang ini.

(2) Penyelidikan, penyidikan, dan penuntutan sebagaimana dimaksud pada ayat (1) dilakukan berdasarkan perintah dan bertindak untuk dan atas nama Komisi Pemberantasan Korupsi.

(3) Penyelidik, penyidik, dan penuntut umum yang menjadi pegawai pada Komisi Pemberantasan Korupsi, diberhentikan sementara dari instansi kepolisian dan kejaksaan selama menjadi pegawai pada Komisi Pemberantasan Korupsi.

Pasal 40:

Komisi Pemberantasan Korupsi tidak berwenang mengeluarkan surat perintah penghentian penyidikan dan penuntutan dalam perkara tindak pidana korupsi.

Pasal 44:

(1) Jika penyelidik dalam melakukan penyelidikan menemukan bukti permulaan yang cukup adanya dugaan tindak pidana korupsi dalam waktu paling lambat 7 (tujuh) hari kerja, terhitung sejak tanggal ditemukan bukti permulaan yang cukup tersebut, penyelidik melaporkan kepada Komisi Pemberantasan Korupsi.

(2) Bukti permulaan yang cukup dianggap telah ada apabila telah ditemukan sekurangkurangnya 2 (dua) alat bukti, termasuk dan tidak terbatas pada informasi atau data yang diucapkan, dikirim, diterima, atau disimpan secara biasa maupun elektronik atau optik.

(3) Dalam hal penyelidik melakukan tugasnya tidak menemukan bukti permulaan yang cukup sebagaimana dimaksud pada ayat (1) penyelidik melaporkan kepada Komisi Pemberantasan Korupsi dan Komisi Pemberantasan Korupsi menghentikan penyelidikan.

(4) Dalam hal Komisi Pemberantasan Korupsi berpendapat bahwa perkara tersebut diteruskan. Komisi Pemberantasan Korupsi melaksanakan penyidikan sendiri atau dapat melimpahkan perkara tersebut kepada penyidik kepolisian atau kejaksaan.

(5) Dalam hal penyidikan dilimpahkan kepada kepolisian atau kejaksaan sebagaimana dimaksud pada ayat (4), kepolisian atau kejaksaan wajib melaksanakan koordinasi dan melaporkan perkembangan penyidikan kepada Komisi Pemberantasan Korupsi.

Dari paparan di atas, jelas kiranya Komisi Pemberantasan Korupsi mempunyai kewenangan yang sangat luas dalam usaha pemberantasan tindak pidana korupsi, tetapi sangat disayangkan tidak mempunyai sumber daya manusia yang memadai sehingga harus mengangkat dari pihak kepolisian ataupun kejaksaan sebagai pegawai yang berfungsi melakukan penyidikan dan penuntutan.

Disfungsionalisasi birokrasi terlihat dari dualisme dalam mekanisme pemeriksaan tindak pidana korupsi dari lembaga-lembaga yang menangani tindak pidana korupsi tersebut, yaitu: 
1. Kepolisian atau kejaksaan sebagai penyidik, diteruskan ke kejaksaan sebagai penuntut umum yang melimpahkan ke pengadilan untuk diperiksa dan diputus (Pengadilan Negeri- Pengadilan Tinggi- dan Mahkamah Agung).

2. Komisi Pemberantasan Korupsi yang mempunyai fungsi penyelidikan, penyidikan, dan penuntutan, serta meneruskan ke pengadilan tindak pidana korupsi (merupakan pengadilan khusus) untuk diperiksa dan diputus (pengadilan tindak pidana korupsi pada tingkat pertama, tingkat banding, dan kasasi yang terdiri atas hakim biasa dan hakim ad hoc).

Keadaan dualisme ini apabila dikaji dari birokrasi sistem peradilan pidana terpadu, tidak sesuai dengan harapan. Sistem peradilan pidana merupakan jaringan peradilan yang menggunakan hukum pidana sebagai sarana bekerjanya, baik hukum pidana materiil, hukum pidana formil, maupun hukum pelaksanaan pidana. Dalam pengertian struktural, sistem peradilan pidana harus diartikan sebagai kerja sama antara pelbagai subsistem peradilan pidana (kepolisian, kejaksaan, pengadilan, dan lembaga pemasyarakatan, serta advokat) untuk mencapai tujuan tertentu yaitu resosialisasi pelaku tindak pidana (jangka pendek), mencegah kejahatan (jangka menengah) dan untuk kesejahteraan dan keamanan masyarakat (jangan panjang). Dalam arti kultural, sistem peradilan pidana merupakan jalinan konsistensi sikap, pandangan terhadap nilai, bahkan filosofi yang secara seragam harus dihayati oleh pelbagai subsistem peradilan pidana dalam kerangka tujuan tertentu dan berhubungan dengan model-model sistem peradilan pidana yang dianut.

Hal yang signifikan adalah peranan pelaku sistem yang committed terhadap spirit dan etika profesional dalam penegakan hukum yang ada, diperlukan tanggung jawab, tidak hanya tanggung jawab yang bersifat eksternal dalam rangka menghasilkan keluaran yang positif dari keseluruhan sistem peradilan. Keterpaduan harus mengandung interdependensi, interaksi dan interkoneksi, tidak boleh mengandung overlapping di dalam fungsi dan kewenangan yang ada pada masing-masing subsistem. Tanggung jawab mengandung dimensi administratif (administrative responsibility), yang menuntut kualitas dari administrasi perkara, dimensi prosedural (prosedural responsibility), yang menuntut ketepatan hukum acara yang digunakan dan dimensi substantif (substantive responsibility) yang berkaitan dengan akurasi pengaitan antara fakta dan hukum yang berlaku.

\section{Peran Pengawasan dalam mewujutkan berfungsinya Birokrasi}

Salah satu upaya untuk membenahi dan mencegah terjadinya korupsi adalah tidak saja diperlukan adanya peningkatan kualitas pelayanan publik melalui penyelenggaraan 
pemerintah yang baik dan bersih, dengan melaksanakan prinsip good governance tetapi juga dengan mengakselerasi sinergi pemberantasan korupsi secara integral dan sistemik, sehingga birokrasi dapat berjalan sesuai dengan fungsinya masing-masing. Akselerasi adalah proses mempercepat sedangkan sinergi adalah kegiatan yang saling menunjang dan kesemuanya itu dilakukan secara integral dengan melibatkan seluruh instansi, lembaga negara maupun segenap lapisan masyarakat secara terpadu dan sistemik.

Untuk dapat mewujutkan akselerasi sinergi pemberantasan korupsi secara integral dan sistemik, sebagai suatu rangkaian kegiatan, maka diperlukan adanya suatu pengawasan yang merupakan bagian dari sistem manajemen. Pengawasan adalah salah satu fungsi manajemen yang sangat diperlukan dan mutlak dibutuhkan dalam suatu organisasi, lebih-lebih dalam organisasi pemerintah atau negara.

Keberadaan lembaga pengawasan pada suatu organisasi, hakekatnya merupakan suatu alat atau sarana yang berfungsi untuk mengontrol organisasi tersebut dengan segala perlengkapannya, termasuk sumber daya manusianya agar dapat berjalan atau berfungsi sesuai dengan tujuan, rencana organisasi dengan tepat waktu dan tepat sasaran, tidak menyimpang atau bertentangan dengan ketentuan yang telah digariskan oleh organisasi atau peraturan perundang-undangan.

Komponen-komponen pemberantasan korupsi baik eksekutif yaitu kejaksaan dan kepolisian, yudikatif yaitu Mahkamah Agung juga lembaga independen yaitu Komisi Pemberantasan Korupsi tentunya memerlukan suatu mekanisme pengawasan sebagai rangkaian bekerja dari suatu sistem manajemen penegakan hukum yang integral dan sistemik. Pengawasan tersebut adalah dalam bentuk internal maupun eksternal. Pengawasan intern berarti pengawasan dilakukan oleh badan yang secara organisatoris/struktural masih masuk ke dalam lingkungan pemerintah itu sendiri, sedangkan kontrol ekstern adalah pengawasan yang dilakukan oleh badan/lembaga yang secara organisatoris/struktural berada di luar pemerintah. Selanjutnya ditinjau dari segi waktu dilaksanakannya pengawasan dibedakan menjadi dua jenis, yaitu a-priori, pengawasan dilaksanakan sebelum dikeluarkannya keputusan atau ketetapan pemerintah, dan a-posteriori, pengawasan yang dilaksanakan sesudah keluarnya keputusan atau ketetapan pemerintah. Lebih lanjut dari segi objek terdiri dari segi hukum (rechtmatigheid) dan kontrol dari segi kemanfaatan (doelmatigheid).

Menurut Inpres Nomor 15 Tahun 1983 tentang Pedoman Pelaksanaan Pengawasan terdapat 2 (dua) bentuk pengawasan yaitu: 
1. Pengawasan yang dilakukan oleh pimpinan/atasan masing-masing satuan organisasi/ satuan kerja terhadap bawahannya atau yang biasa disebut pengawasan melekat (Waskat).

2. Pengawasan yang dilakukan oleh aparat pengawasan fungsional yang bersangkutan atau pengawasan fungsional (Wasnal).

Pengawasan melekat adalah serangkaian kegiatan yang bersifat sebagai pengendalian yang terus menerus, dilakukan oleh atasan langsung terhadap bawahannya. Secara preventif atau represif agar pelaksanaan tugas bawahan tersebut berjalan secara efektif dan efisien sesuai dengan rencana kegiatan dan peraturan perundang-undangan yang berlaku. Sedangkan yang menjadi sasaran pengawasan melekat adalah meningkatkan disiplin serta prestasi kerja serta pencapaian sasaran pelaksanaan tugas, menekan hingga sekecil mungkin penyalahguna-an wewenang dan menekan hingga sekecil mungkin kebocoran serta pemborosan keuangan negara dan segala bentuk pungutan liar. Secara umum pelaksanaan pengawasan melekat meliputi kegiatan pemantauan, pengamatan, pemeriksaan, mengidentifikasi dan menganalisis gejala-gejala penyimpangan, perumusan tindak lanjut yang tepat, permintaan laporan pelaksanaan tugas dari bawahan, pemberian penilaian atas hasil kerja bawahan dan melakukan pembinaan terhadap bawahan serta menjalin kerjasama dengan aparat pengawasan fungsional.

Sedangkan pengawasan fungsional adalah pengawasan yang dilakukan oleh aparat pengawasan secara funsional baik intern pemerintah maupun ekstern pemerintah, yang dilakukan terhadap pelaksanaan tugas umum pemerintah dan pembangunan agar sesuai dengan rencana dan peraturan perundang-undangan yang berlaku.

Dalam rangka good governance, penyelenggaraan pengawasan melekat dan pengawasan fungsional dilingkungan institusi penegak hukum dalam penanganan laporan pengaduan hendaknya didasarkan pada prinsip transparansi dan akuntabilitas, dimana pelapor berhak untuk mengetahui sejauhmana laporan pengaduannya diproses dan hasil pemeriksaan terhadap terlapor. Jika hak pelapor tidak dipenuhi maka pelapor dapat melaporkan kepada pimpinan untuk selanjutnya dilakukan penilaian.

Sebagai institusi penegak hukum baik Kepolisian, Kejaksaan dan Mahkamah Agung atau Komisi Pemberantasan Korupsi yang sangat rentan terhadap praktek-praktek penyimpangan serta penyalahgunaan wewenang terutama yang berkaitan dengan penanganan perkara maka keberadaan lembaga pengawasan hendaknya tidak saja bersifat normatif atau hendaknya berorientasi kepada penindakan, tetapi juga bersifat 
implementatif atau aplikatif yang berorientasi kepada upaya pencegahan sangat dibutuhkan.

Tujuan dari pengawasan hakekatnya agar seluruh aparat penegak hukum dapat mengemban tugasnya dengan baik dan penuh rasa tanggung jawab, serta menghindarkan diri dari sikap, perilaku dan tutur kata yang bertentangan dengan peraturan perundangundangan sehingga organisasi atau institusi penegak hukum dapat menjadi: Acceptable, dapat diterima semua pihak; Profitable, dapat memberi manfaat; Applicable, dapat melakukan tugas organisasi dan Accountable, dapat dipertanggungjawabkan. Dengan kata lain agar visi dan misi yang sudah ditetapkan organisasi dapat tercapai sebagaimana mestinya (Marwan Effendy, 2012: 17).

Berdasarkan kepada hakekat dari tujuan pengawasan di atas, apabila pengawasan dijalankan sesuai dengan mekanisme pengawasan melekat maupun pengawasan fungsional yang telah ditetapkan, maka setiap penyimpangan dapat dicegah sejak dini atau diminimalisir, sedangkan penjatuhan hukuman disiplin diharapkan dapat menimbulkan efek cegah dan efek penjeraan.

Diharapkan kedepan secara perlahan stigma negatif masyarakat terhadap kredibilitas institusi penegak hukum yang sudah terlanjur terbentuk dapat dieliminasi dan tentunya tidak boleh dibiarkan berlanjut. Upaya pemulihan kembali (recovery) kredibilitas institusi penegak hukum tersebut salah satunya adalah dengan membangun kembali kepercayaan publik (public trust building), melalui peningkatan integritas aparaturnya.

Pengawasan eksternal kejaksaan dilaksanakan oleh Komisi Kejaksaan yang dibentuk berdasarkan Pasal 38 Undang-Undang Nomor 16 Tahun 2004 tentang Kejaksaan Republik Indonesia, merupakan bentuk peran serta masyarakat untuk membenahi Kejaksaan sebagai institusi penegak hukum, sekaligus merupakan mitra strategis lembaga pengawasan internal yang telah ada. Dengan adanya komisi pengawasan eksternal ini, tidak saja dapat memacu kinerja aparat pengawasan internal agar dapat melakukan tugasnya secara efektif, efisien dan terstruktur, tetapi ke depan dapat mendorong kinerja aparatur kejaksaan akan semakin baik dan sesuai dengan harapan masyarakat. Dengan demikian diharapkan dapat membuat ruang gerak untuk melakukan penyimpangan dan penyalahgunaan wewenang semakin terbatas.

Sedangkan pengawasan eksternal kepolisian dilakukan oleh Komisi Kepolisian Nasional. Komisi Kepolisian Nasional merupakan amanat dari Pasal 37 ayat (2) jo Pasal 39 ayat (3) Undang-Undang Nomor 2 Tahun 2002 tentang Kepolisian Negara Republik Indonesia. Komisi Kepolisian Nasional melaksanakan fungsi pengawasan fungsional 
terhadap kinerja Polisi Republik Indonesia untuk menjamin profesionalisme dan kemandirian Polisi Republik Indonesia di mana pelaksanaan fungsi pengawasan fungsionalnya dilakukan melalui kegiatan pemantauan dan penilaian terhadap kinerja dan integritas anggota Polisi Republik Indonesia dan pejabat Polisi Republik Indonesia.

Pengawasan eksternal Mahkamah Agung dilaksanakan oleh Komisi Yudisial berdasarkan Undang-Undang Nomor 22 Tahun 2004 tentang Komisi Yudisial yang disahkan di Jakarta pada tanggal 13 Agustus 2004 sebagai tindak lanjut dari amandemen ketiga Undang-Undang Dasar 1945. Komisi Yudisial berwenang mengusulkan pengangkatan Hakim Agung dan wewenang lain dalam rangka menjaga dan menegakkan kehormatan, keluhuran martabat, serta perilaku hakim.

Namun sampai saat ini belum ada lembaga eksternal yang mengawasi kinerja dari Komisi Pemberantasan Korupsi. Keberadaan lembaga eksternal ini diharapkan dapat bekerja dengan profesional dan proporsional seperti lembaga-lembaga pengawas eksternal lainnya guna memberikan kontribusi positif baik pada Komisi Pemberantasan Korupsi sendiri selaku lembaga penegak hukum maupun bagi penegakan supremasi hukum di Indonesia.

Sedangkan untuk pengawasan fungsional (internal) pada Kejaksaan Republik Indonesia, pengawasan fungsional (internal) dilakukan oleh jajaran Jaksa Agung Muda. Pengawasan fungsional untuk Kepolisian Republik Indonesia dilakukan oleh Divisi Profesi dan Pengamanan Polisi. Untuk Mahkamah Agung dilakukan oleh Ketua Muda Mahkamah Agung urusan Pengawasan dan Pembinaan. Sedangkan untuk Komisi Pemberantasan Korupsi mempunyai mekanisme pengawasan internal yaitu melalui Deputi Bidang Pengawasan Internal dan Pengaduan Masyarakat.

Sebagai suatu keseimbangan seharusnya perlu dipikirkan adanya lembaga yang juga mengawasi Komisi Pemberantasan Korupsi secara eksternal, agar ada check and balance serta mencegah penyalahgunaan wewenang dan dapat meningkatkan profesionalisme Komisi Pemberantasan Korupsi.

\section{E. Simpulan}

Seluruh aparat birokrasi di negara manapun adalah abdi negara dan abdi masyarakat, “public servant” aparat yang dalam tugasnya berorientasi pada pelayanan, maka sesuai profesi dan fungsi aparat harus berperilaku fungsional dalam melaksanakan tugastugasnya. Dalam menghadapi klien (rakyat), aparat tidak seharusnya sombong, pura-pura sibuk, acuh tak acuh, diskriminatif, kaku, berbelit-belit (red tape), kerja asal-asalan, mengutamakan kepentingan pribadi, melampaui batas wewenang, boros, interest pribadi, 
dan sikap perilaku lain yang tidak menyenangkan. Setiap aparat birokrasi diharapkan mempunyai kompetensi yang sedikitnya memenuhi 3 (tiga) syarat yaitu: knowledge, skill dan attitude.

Penanganan tindak pidana korupsi saat ini jangan hanya mengedepankan tindakan penindakan saja atau represif, tetapi juga harus mengedepankan tindakan preventif. Penanganan tindak pidana korupsi saat ini tidak bisa lagi hanya bersifat parsial dengan mengandalkan undang-undang, tetapi juga dengan menggunakan instrumen lain secara terpadu. Disamping itu peran pengawasan baik internal maupun eksternal sangat penting keberadaannya sebagaimana terkandung dalam prinsip manajemen, sehingga birokrasi dapat berfungsi dengan baik guna mewujutkan suatu akselerasi sinergi pemberantasan korupsi yang integral dan sistemik.

\section{Daftar Pustaka}

Antonius Sujata. 2000. Reformasi dalam Penegakan Hukum, Jakarta, Penerbit Djambatan.

Anwary, S. 2005. Quo Vadis Pemberantasan Korupsi Di Indonesia, Jakarta, Institute of Socio-Economics And Political Studies People Message.

David Osborne and Ted Gabler. 1995. Mewirausahakan Birokrasi (Reinveinting Goverment), How the Interpreneursial Spirit is Transforming The Public Sector, A Plume Book USA, terjemahan Abdul Roshid, Pustaka Binaman Presindo, Jakarta.

Ermansjah Djaja. 2010. Meredesain Pengadilan Tindak Pidana Korupsi, Jakarta, Sinar Grafika.

Henry Cambell Black. 1990. Black's Law Dictionary, Edisi VI, St. Paul Minesota, West Publishing.

Jeremy Bentham. 2006. Teori Perundang-undangan (Prinsip-prinsip Legalisasi, Hukum Perdata dan Hukum Pidana), Bandung, Nuansa.

Lawrence M. Friedman. 1975. The Legal System, A Social Perspective, New York, Russel Sage Foundation.

Marcella Elwina S. 2011. Pendidikan Anti Korupsi: Sebuah Langkah Strategis Membangun Integritas Bangsa, Makalah dalam Seminar Nasional Pendidikan Integritas di Semarang, 5 Juli 2011.

Marwan Effendy. 2012. Kapita Selekta Hukum Pidana, Jakarta, Referensi.

Nyoman Serikat Putra Jaya. 2008. Beberapa Pemikiran Kearah Pengembangan Hukum Pidana, Bandung, Citra Aditya Bakti. 
Peter Blow dan W. Meyer Marshall. 1987. Birokrasi dalam Masyarakat Modern, terjemahan Gery R. Yusuf, UI Press, Jakarta.

Romli Atmasasmita. 2003. Korupsi, Good Governance dan Komisi Anti Korupsi di Indonesia, Jakarta, Badan Pembinaan Hukum Nasional Departemen Kehakiman dan Hak Asasi Manusia Republik Indonesia.

Satjipto Rahardjo. 2007. Membedah Hukum Progresif, Jakarta, Penerbit Buku Kompas. - 2008. Membedah Hukum Progresif, Jakarta, Penerbit Buku Kompas. 2009 Penegakan Hukum Suatu Tinjauan Sosiologis, Yogyakarta, Genta Publishing. 